\title{
Cassiae semen: A review of its phytochemistry and pharmacology (Review)
}

\author{
XIAOXV DONG, JING FU, XINGBIN YIN, CHUNJING YANG, XIN ZHANG, \\ WENPING WANG, XUEYING DU, QINGLING WANG and JIAN NI \\ Department of Chinese Medicine Pharmaceuticals, School of Chinese Materia Medica, \\ Beijing University of Chinese Medicine, Beijing 100102, P.R. China
}

Received June 2, 2016; Accepted April 11, 2017

DOI: $10.3892 / \mathrm{mmr} .2017 .6880$

\begin{abstract}
Cassiae semen (Leguminosae), a well-known traditional Chinese medicine, has been used for a number of centuries in areas of Southeast Asia, including Korea, Japan and China. The present review aims to provide updated and comprehensive information, on the botany, phytochemistry and pharmacology of Cassiae semen. The available information on Cassiae semen was collected using several different resources, including classic books on Chinese herbal medicine and a number of scientific databases, including the China Academic Journals full-text database, PubMed, SciFinder, the Web of Science and Science Direct. To date $>70$ chemical compounds have been isolated from Cassiae semen, and the major components have been determined to be anthraquinones, naphthopyrones and volatile oil. The crude extracts and pure compounds of Cassiae semen have been used as effective agents in preclinical and clinical practice due to their beneficial activities, including antihyperlipidemic, antidiabetic, neuroprotective, hepatoprotective, antibacterial, antioxidant and hypotensive activities. With the body of reported data, it has been suggested that Cassiae semen has convincing medicinal potential. However, the pharmacological mechanisms of the main bioactive compounds and the association between structure and activity require further investigation.
\end{abstract}

\section{Contents}

1. Introduction

2. Ethnobotany

Correspondence to: Professor Jian Ni, Department of Chinese Medicine Pharmaceuticals, School of Chinese Materia Medica, Beijing University of Chinese Medicine, 11 North Third Ring Road, Beijing 100102, P.R. China

E-mail: njtcm@263.net

Key words: Cassiae semen, phytochemistry, pharmacology

\section{Phytochemistry \\ 4. Pharmacology \\ 5. Conclusions}

\section{Introduction}

Cassiae semen, also known as 'Juemingzi' in Chinese, is the dry and mature seed of Cassia obtusifolia L. or C. tora L., which belong to the Cassia genus of Leguminosae (1). It is cultivated in Korea, Japan and China, and is commonly consumed as a roasted tea $(2,3)$. In traditional Chinese medicine, it has been used in treatments for hyperlipemia, diabetes mellitus, Alzheimer's disease, acute liver injury, inflammation, photophobia, headache, dizziness and hypertension (4-6).

Phytochemical investigations have isolated and identified $>70$ compounds, including anthraquinones, naphthopyrones, volatile oils and sterols $(7,8)$. Among these, anthraquinones are the primary functional components and possess a wide spectrum of pharmacological properties (9-11), including antihyperlipidemic, neuroprotective, hepatoprotective, antibacterial and antimutagenic activities (12-14). Naphthopyrones, other primary components, exhibit antidiabetic $(15,16)$, antimicrobial (17), antiestrogenic (18), antiallergic (19) and anthelmintic effects (20). At present, the Pharmacopoeia of the People's Republic of China recommends the use of chrysophanol and aurantio-obtusin as the indicator components, and the quality of Cassiae semen is evaluated primarily by assessing the content of these two compounds (1).

The purpose of the present review is to provide comprehensive information on the ethnobotany, phytochemistry and pharmacology of Cassiae semen collated from previous studies, in order to facilitate the further study and application of Cassiae semen, as well as generate a novel basis for the associations between structure and activity, and their molecular mechanisms of action.

\section{Ethnobotany}

C. obtusifolia is similar to $C$. tora in terms of botanical morphology. The two are an annual, erect, stout herb, $\sim 1-2 \mathrm{~m}$ in length, and their leaves are paripinnate, typically pubescent and are $4-8 \mathrm{~cm}$ in length with a conical gland between each of the two lowest pairs of leaflets. Leaflets are formed of 3 leaf 
pairs and are glaucous, membranous, glabrous or pubescent, and have obcordate or obovate oblong morphology $(2-6 \mathrm{~cm}$ long x $1.5-2.5 \mathrm{~cm}$ wide); the base is somewhat oblique, usually rounded and there are 8-10 pairs of main nerves. The petiolules are 1.5-2 $\mathrm{mm}$ in length and their stipules are linear, pilose and caducous. It blossoms from July to September and produces fruit from September to October. Flowers are usually in subsessile pairs in leaf axils, the pedicels are filiform and are $1-1.5 \mathrm{~cm}$ in length. Calyces are ovate, glabrous, membranous and comprised of five-parts; there are five petals, which are pale yellow, oblong, obtuse and the upper petal (standard) is two-lobed. The flowers have 10 stamens, while the upper three are reduced to minute staminodes. The pods are slender, puberulous, subtetragonous, obliquely septate and, are $\sim 15 \mathrm{~cm}$ in length and 3-4 mm in width.

However, the seeds of $C$. obtusifolia are a dark brown or green-brown, rhombohedral or short cylindrical, and are 3-7 $\mathrm{mm}$ in length and 2-4 $\mathrm{mm}$ in width. While C. tora seeds are a light brown, shiny, short cylindrical, and are $3-5 \mathrm{~mm}$ in length and 2-3 $\mathrm{mm}$ in width $(1,21)$.

C. obtusifolia is cultivated in multiple provinces of China, including Henan, Hubei, Shanxi, Sichuan, Zhejiang and Anhui, and also other countries, including Korea, India and Japan. It is primarily distributed in moist and sunny places, in hillside shrubs and in the sandy soil of river banks (21).

As a widely used traditional Chinese medicine, there are some adulterants of this plant, including the seeds of C.occidentalis (Leguminosae), C. sophera (Leguminosae) and Sesbania aculeata Pers (Papilionaceae) (22-24). To date, a number of methods have been developed to identify and distinguish these, including experiential identification, morphological identification, ultraviolet spectrophotometry, the thin layer chromatography method, high performance liquid chromatography (HPLC), HPLC-coupled with time-of-flight and ion trap mass spectrometry, and SDS-PAGE (25-28). Among these methods, the HPLC method is regarded as the most popular method for evaluating the quality and authenticity of Cassiae semen. Chrysophanol and aurantio-obtusin are used as the indicator compounds to characterize the quality of this plant and the minimum contents are defined as 0.20 and $0.080 \%$, respectively, in the Pharmacopoeia of the People's Republic of China (1).

\section{Phytochemistry}

A number of compounds, including anthraquinones, naphthopyrones, volatile oils and sterols, have been isolated from Cassiae semen. Anthraquinones and naphthopyrones, which exhibit multiple pharmacological activities, are considered the primary active ingredients of Cassiae semen. All compounds isolated from Cassiae semen are listed in Table I, and their chemical structures are displayed in Figs. 1-3.

Anthraquinones. Cassiae semen contains structurally diverse and biologically active anthraquinones. Thus far, $\sim 53$ anthraquinones have been isolated and identified. The predominant anthraquinones are emodin-type anthraquinones, which include emodin, chrysophanol, physcion, aloe-emodin, rhein, obtusin, chryso-obtusin, aurantio-obtusin, obtusifolin, questin, 1-desmethylaurantio-obtusin, 1-desmethylobtusin, 1-desmethylchryso-obtusin, chrysophanol-10,10'-bianthrone, 1,2-dihydroxyanthraquinone, 2-hydroxyemodin-1-methylether, alaternin, 1,3-dihydroxy-6-methoxy-7-methyl anthraquinone, 1-hydroxy-3,7-diformyl anthraquinone, chrysarobin, 8-O-methylchrysophanol, 1-O-methylemodin, 1,2-dimethoxy-8-hydroxy-3-methyl-9,10-anthraquinone and 1,2,7-trimethoxyl-6,8-dihydroxy-3-methylanthraquinone (compounds 1-24, respectively; Fig. 1); these have all been isolated from Cassiae semen (29-38). There are also many combined anthraquinones (compounds 25-46; Fig. 1), which have been isolated from the seeds of $C$. obtusifolia or $C$. tora $(3,7,30,36,39-46)$.

Naphthopyrones. Naphthopyrones are the other characteristic components in Cassiae semen. In 1969, torachrysone, rubrofusarin and rubrofusarin-6-O- $\beta$-D-gentiobioside were isolated from $C$. tora seeds (compounds 47-49, respectively; Fig. 2) $(47,48)$. Subsequently, toralactone, rubrofusarin triglucoside, cassiaside, nor-rubrofusarin gentiobioside, cassiaside $\mathrm{B}$, cassiaside $\mathrm{C}$, torachrysone apiglucoside, torachrysone gentiobioside, torachrysone tetraglucoside, cassiatoroside, demethylflavasperone gentiobioside and cassialactone gentiobioside were isolated from C. tora seeds (compounds 50-61, respectively; Fig. 2) (17,28,49-51). In addition, cassiaside B and cassiaside $\mathrm{C}$ were identified in the seeds of $C$. obtusifolia (52). Other naphthopyrones, including torosachrysone, isotoralactone, cassialactone, cassiaside $\mathrm{B}_{2}$, cassiaside $\mathrm{C}_{2}$, nor-rubrofusarin-6-O- $\beta$-D (6'-O-acetyl) glucopyranoside and 1-hydroxyl-2-acetyl-3,8-dimethoxy-6-O-[ $\beta$-D-apiofuranosyl$(1 \rightarrow 2)$ - $\beta$-D-glucopyranosyl]-naphthalene were also isolated from C. obtusifolia seeds (compounds 62-68, respectively; Fig. 2) (19,53-55).

Volatile oils. Li (56) extracted the volatile oils from Cassiae semen by steam distillation, and subsequently identified 37 components according to the gas chromatography/mass spectrometry analysis. Among these peaks, the major volatile components were 9-octadecenoic acid (E) (22.15\%), n-hexadecanoic acid (12.53\%), 9,10-anthracenedione, 1,8-dihydroxy-3-methyl (7.66\%), octadecanoic acid (4.56\%) and 13-octadecenoic acid methyl ester (Z) (3.84\%) (56).

Other compounds. A range of other components have been isolated from Cassiae semen, including malvalic acid, sterculic acid, mandelic acid, campesterol, aspidinol and 5,7-dihydroxychromone (compounds 69-74, respectively; Fig. 3) $(5,57,58)$. In addition, the four flavonoid compounds, chrysin, chrysin-7-O- $\beta$-D-glucoside, galangin and cyanidenon, were also obtained and identified from Cassiae semen (compounds 75-78, respectively; Fig. 3) (58).

\section{Pharmacology}

Cassiae semen exerts a great variety of pharmacological activities due to its complex bioactive compounds. An overview of the pharmacological studies on Cassiae semen is presented in detail in the following sections.

Antihyperlipidemic activity. In traditional Chinese herbal medicine, Cassiae semen is used for the prevention and 
Table I. Chemical compounds isolated from Cassiae semen.

\begin{tabular}{|c|c|c|c|}
\hline Classification & No. & Chemical component & (Refs.) \\
\hline \multirow[t]{46}{*}{ Anthraquinones } & 1 & Emodin & $(37,38)$ \\
\hline & 2 & Chrysophanol & (34) \\
\hline & 3 & Physcion & $(34)$ \\
\hline & 4 & Aloe-emodin & $(38)$ \\
\hline & 5 & Rhein & $(38)$ \\
\hline & 6 & Obtusin & $(35)$ \\
\hline & 7 & Chryso-obtusin & $(35)$ \\
\hline & 8 & Aurantio-obtusin & $(35)$ \\
\hline & 9 & Obtusifolin & $(35)$ \\
\hline & 10 & Questin & $(36)$ \\
\hline & 11 & 1-desmethylaurantio-obtusin & $(36)$ \\
\hline & 12 & 1-desmethylobtusin & $(36)$ \\
\hline & 13 & 1-desmethylchryso-obtusin & $(36)$ \\
\hline & 14 & Chrysophanol-10,10'-bianthrone & $(36)$ \\
\hline & 15 & 1,2-dihydroxyanthraquinone & $(7)$ \\
\hline & 16 & 2-hydroxyemodin-1-methylether & (7) \\
\hline & 17 & Alaternin & $(29)$ \\
\hline & 18 & 1,3-dihydroxy-6-methoxy-7-methyl anthraquinone & $(30)$ \\
\hline & 19 & 1-hydroxy-3,7-diformyl anthraquinone & $(30)$ \\
\hline & 20 & Chrysarobin & $(30,31)$ \\
\hline & 21 & 8-O-methylchrysophanol & $(32)$ \\
\hline & 22 & 1-O-methylemodin & $(32)$ \\
\hline & 23 & 1,2-dimethoxy-8-hydroxy-3-methyl-9,10-anthraquinone & $(32)$ \\
\hline & 24 & 1,2,7-trimethoxyl-6,8-dihydroxy-3-methylanthraquinone & $(33)$ \\
\hline & 25 & Gluco-aurantioobtusin & $(39)$ \\
\hline & 26 & Emodin-6-glucoside & $(30)$ \\
\hline & 27 & Physcion-8-O- $\beta$-D-glucopyranoside & $(7,40)$ \\
\hline & 28 & Physcion-8-O- $\beta$-gentiobioside & $(41)$ \\
\hline & 29 & Emodin-1-O- $\beta$-gentiobioside & $(41)$ \\
\hline & 30 & Obtusifolin-2-O- $\beta$-D-glucoside & $(42)$ \\
\hline & 31 & Chysophanol-1-O- $\beta$-gentiobioside & $(41)$ \\
\hline & 32 & Alaternin-1-O- $\beta$-D-glucopyranoside & $(7)$ \\
\hline & 33 & Alaternin-2-O- $\beta$-D-glucopyranoside & $(29)$ \\
\hline & 34 & Aurantio-obtusin-6-O- $\beta$-D-glucopyranoside & $(43)$ \\
\hline & 35 & Chryso-obtusin-2-O- $\beta$-D-glucopyranoside & $(7)$ \\
\hline & 36 & Obtusifolin-2-O- $\beta$-D-(6'-O-acetyl) glucopyranoside & $(44)$ \\
\hline & 37 & Emodin-8-O- $\beta$-D-glucopyranoside & $(45)$ \\
\hline & 38 & 2-methoxyl-chrysophanol-8-O- $\beta$-D-glucopyranoside & $(46)$ \\
\hline & 39 & 1-demethylaurantio-obtusin-2-O- $\beta$-D-glucopyranoside & $(43)$ \\
\hline & 40 & 1,7,8-trimethoxyl-2-hydroxyl-3-methylanthraquinone-2-O- $\beta$-D-glucopyranoside & (33) \\
\hline & 41 & 1,7-diinethoxyl-2,8-dihydroxyl-3-methylanthraquinone-2-O- $\beta$-D-glucopyranoside & (33) \\
\hline & 42 & 1,2,7-trimethoxyl-6,8-dihydroxy-3-methylanthraquinone-6-O- $\beta$-D-glucopyranoside & (33) \\
\hline & 43 & 2,8-dimethoxyl-1,6-dihydroxy-3-methylanthraquinone-6-O- $\beta$-D-glucopyranoside & $(33)$ \\
\hline & 44 & $\begin{array}{l}\text { 1-[( } \beta \text {-D-glucopyranosyl- }(1 \rightarrow 3)-O-\beta \text {-glucopyranosyl- }(1 \rightarrow 6)-O-\beta \text { - } \\
\text { D-glucopyranosyl)oxy]-8-hydroxy-3-methyl-9,10-anthraquinone }\end{array}$ & $(42)$ \\
\hline & 45 & $\begin{array}{l}\text { 1-[( } \beta \text {-D-glucopyranosyl- }(1 \rightarrow 6)-O-\beta \text {-glucopyranosyl- }(1 \rightarrow 3)-O-\beta \text { - } \\
\text { D-glucopyranosyl- }(1 \rightarrow 6)-O-\beta \text {-D-glucopyranosyl)oxy]-8-hydroxy- } \\
\text { 3-methyl-9,10-anthraquinone }\end{array}$ & $(42)$ \\
\hline & 46 & 4,6,7-trimethoxyl-aloe-emodin-8-O- $\beta$-D-glucopyranoside & $(46)$ \\
\hline \multirow[t]{3}{*}{ Naphthopyrones } & 47 & Torachrysone & $(48)$ \\
\hline & 48 & Rubrofusarin & $(47)$ \\
\hline & 49 & Rubrofusarin-6-O- $\beta$-D-gentiobioside & $(47)$ \\
\hline
\end{tabular}


Table I. Continued.

\begin{tabular}{|c|c|c|c|}
\hline Classification & No. & Chemical component & (Refs.) \\
\hline & 50 & Toralactone & (49) \\
\hline & 51 & Rubrofusarin triglucoside & (17) \\
\hline & 52 & Cassiaside & $(50)$ \\
\hline & 53 & Nor-rubrofusarin gentiobioside & (17) \\
\hline & 54 & Cassiaside B & $(50)$ \\
\hline & 55 & Cassiaside C & $(50)$ \\
\hline & 56 & Torachrysone apiglucoside & (17) \\
\hline & 57 & Torachrysone gentiobioside & (17) \\
\hline & 58 & Torachrysone tetraglucoside & $(17)$ \\
\hline & 59 & Cassiatoroside & $(51)$ \\
\hline & 60 & Demethylflavasperone gentiobioside & $(17)$ \\
\hline & 61 & Cassialactone gentiobioside & $(28)$ \\
\hline & 62 & Torosachrysone & $(53)$ \\
\hline & 63 & Isotoralactone & $(53)$ \\
\hline & 64 & Cassialactone & $(53)$ \\
\hline & 65 & Cassiaside $\mathrm{B}_{2}$ & (19) \\
\hline & 66 & Cassiaside $\mathrm{C}_{2}$ & $(19)$ \\
\hline & 67 & Nor-rubrofusarin-6-O- $\beta-\mathrm{D}(6$ '-o-acetyl) glucopyranoside & $(54)$ \\
\hline & 68 & $\begin{array}{l}\text { l-hydroxyl-2-acetyl-3,8-dimethoxy-6-O-[ } \beta \text {-D-apiofuranosyl- } \\
(1 \rightarrow 2)-\beta-D \text {-glucopyranosyl]-naphthalene }\end{array}$ & $(55)$ \\
\hline \multirow[t]{10}{*}{ Other compounds } & 69 & Malvalic acid & $(5,57)$ \\
\hline & 70 & Sterculic acid & $(5)$ \\
\hline & 71 & Mandelic acid & $(5)$ \\
\hline & 72 & Campesterol & $(5)$ \\
\hline & 73 & Aspidinol & $(58)$ \\
\hline & 74 & 5,7-dihydroxychromone & $(58)$ \\
\hline & 75 & Chrysin & $(58)$ \\
\hline & 76 & Chrysin-7-O- $\beta$-D-glucoside & $(58)$ \\
\hline & 77 & Galangin & $(58)$ \\
\hline & 78 & Cyanidenon & $(58)$ \\
\hline
\end{tabular}

treatment of hyperlipidemia. Several Chinese herbal formulations containing Cassiae semen is available in the Chinese market for preventing the formation of atherosclerotic plaques (59). In certain Asian countries, including China and Korea, it is also commonly drunk as a roasted tea to reduce body weight $(60,61)$. Previous studies using mice have evaluated the reductions in blood lipid contents induced by different Cassiae semen extracts obtained through different methods, including supercritical fluid extraction, systematic solvents (petroleum ether, ethyl acetate, n-butanol, 70\% ethanol and water) and ethanol precipitation following water extraction. The results revealed that the n-butanol and ethyl acetate extracts were the most effective $(62,63)$. In addition, the ethanol and aqueous extracts of Cassiae emen significantly decreased the serum levels of total cholesterol (TC), triglyceride (TG) and low-density lipoprotein cholesterol (LDL-C), however, they increased the levels of high-density lipoprotein cholesterol (HDL-C) $(13,64,65)$. Similarly, He et al (66) reported that treatment with the water extract form of $C$. obtusifolia seeds decreased the blood-lipid level by inhibiting cholesterol synthesis. Cho et al (67) demonstrated that soluble fibers from $C$. tora seeds markedly decreased liver TC and TG levels in rats fed with a high-cholesterol diet. The underlying mechanism may be mediated by increasing fecal bile acid excretion and downregulating the production of lipogenic enzymes (67). In addition, soluble fibers decreased the serum levels of TC, TG and LDL-C in patients with type II diabetes without serious adverse effects (2). Liu et al (68) revealed that the ethanol extract of Cassiae semen upregulated the expression levels of peroxisome proliferator-activated receptor (PPAR)- $\gamma$, sterol regulatory element-binding protein-1c, hormone-sensitive lipase and triacylglycerol hydrolase, however, tumor necrosis factor receptor superfamily member 6 was downregulated in adipose tissue. The anti-hyperlipidemia activity of Cassiae semen is primarily due to its antioxidant components, such as anthraquinones and polysaccharides. There are a variety of bioactive anthraquinone components in Cassiae semen, including chrysophanol, physcion, aurantio-obtusin, obtusifolin and emodin, which have been observed to decrease the levels of TC and TG $(69,70)$. Previous studies have demonstrated that anthraquinones isolated from Cassiae semen 
Table II. Pharmacological activities of Cassiae semen.

\begin{tabular}{|c|c|c|c|c|}
\hline $\begin{array}{l}\text { Pharmacological } \\
\text { activities }\end{array}$ & Actions & Extracts/compounds & Application & (Refs.) \\
\hline \multirow[t]{4}{*}{$\begin{array}{l}\text { Anti-hyperlipidemia } \\
\text { activity }\end{array}$} & Reduces blood lipid levels & $\begin{array}{l}\text { SFE, systematic solvents } \\
\text { (petroleum ether, ethyl } \\
\text { acetate, n-butanol, } 70 \% \\
\text { ethanol and water) }\end{array}$ & In vivo & $(62,63)$ \\
\hline & $\begin{array}{l}\text { Decreases the levels of } \mathrm{TC} \text {, } \\
\mathrm{TG} \text { and LDL-C; Increases the } \\
\text { level of HDL-C }\end{array}$ & $\begin{array}{l}\text { Ethanol and aqueous } \\
\text { extracts }\end{array}$ & In vivo & $(13,64,65)$ \\
\hline & $\begin{array}{l}\text { Inhibits the synthesis of } \\
\text { cholesterol }\end{array}$ & Water extract & In vitro & $(66)$ \\
\hline & $\begin{array}{l}\text { Increases fecal bile acid } \\
\text { excretion and downregulates } \\
\text { the production of lipogenic } \\
\text { enzymes }\end{array}$ & Soluble fibers & In vivo & $(67)$ \\
\hline \multirow[t]{4}{*}{$\begin{array}{l}\text { Anti-hyperlipidemia } \\
\text { activity }\end{array}$} & $\begin{array}{l}\text { Upregulates the expression } \\
\text { levels of PPAR } \gamma, \text { SREBP-1c, } \\
\text { HSL and TGH; Downregulates } \\
\text { the levels of FAS }\end{array}$ & Ethanol extract & In vivo & $(68)$ \\
\hline & Decreases TC and TG levels & $\begin{array}{l}\text { Chrysophanol, physcion, } \\
\text { aurantio-obtusin, } \\
\text { obtusifolin and } \\
\text { emodin }\end{array}$ & In vitro & $(69,70)$ \\
\hline & $\begin{array}{l}\text { Decreases TC, TG and } \\
\text { LDL-C levels; Increases } \\
\text { HDL-C levels }\end{array}$ & Anthraquinones & In vivo & (73) \\
\hline & $\begin{array}{l}\text { Binds bile acids and } \\
\text { reduces the absorption } \\
\text { of cholesterol }\end{array}$ & $\begin{array}{l}\text { Water-soluble } \\
\text { polysaccharides }\end{array}$ & In vitro & $(74)$ \\
\hline \multirow[t]{4}{*}{ Anti-diabetic activity } & Inhibits AGEs activity & $\begin{array}{l}\text { Cassiaside, cassiaside } \mathrm{C} \text {, } \\
\text { rubrofusarin-6-O- } \beta \text {-D- } \\
\text { gentiobioside }\end{array}$ & In vitro & $(15)$ \\
\hline & $\begin{array}{l}\text { Inhibits the expression } \\
\text { of TGF-1 and ECM } \\
\text { proteins }\end{array}$ & $\begin{array}{l}\text { Rubrofusarin-6-O- } \beta \text {-D- } \\
\text { gentiobioside, cassiaside }\end{array}$ & In vitro & $(16)$ \\
\hline & $\begin{array}{l}\text { Inhibits AGEs accumulation } \\
\text { and, RAGE and } \\
\text { COX-2 expression }\end{array}$ & Methanol extract & In vitro/vivo & $(75,76)$ \\
\hline & $\begin{array}{l}\text { Downregulates the expression } \\
\text { of TGF- } \beta 1, \text { CTGF and smad3, } \\
\text { and upregulates the protein } \\
\text { expression of smad } 6\end{array}$ & Water extract & In vivo & $(77)$ \\
\hline \multirow[t]{6}{*}{ Neuroprotective activity } & Inhibits AChE activity & Ethanol extract & In vivo & $(6)$ \\
\hline & $\begin{array}{l}\text { Upregulates the expression } \\
\text { of pCREB and BDNF }\end{array}$ & Ethanol extract & In vivo & (78) \\
\hline & $\begin{array}{l}\text { Attenuates secondary calcium } \\
\text { dysregulation and cell death }\end{array}$ & Ethanol extract & In vivo & (79) \\
\hline & $\begin{array}{l}\text { Ameliorates the } \mathrm{A} \beta \text {-induced } \\
\text { synaptic dysfunction model }\end{array}$ & Obtusifolin, alaternin & In vivo & $(80)$ \\
\hline & $\begin{array}{l}\text { Inhibits cell damage and } \\
\text { protects DA neuronal } \\
\text { degeneration }\end{array}$ & Ethanol extract & In vitro/vivo & $(81)$ \\
\hline & $\begin{array}{l}\text { Improves learning and } \\
\text { memory capacity; Inhibits }\end{array}$ & $\begin{array}{l}\text { Protein and anthraquinone } \\
\text { glucosides }\end{array}$ & In vivo & $(82)$ \\
\hline
\end{tabular}

MDA and MAO levels;

Enhances the level of SOD 
Table II. Continued.

Pharmacological activities

Actions

Extracts/compounds

Application

Reference

\section{Hepatoprotective} activity

Antibacterial activity

Antioxidant activity

Hypotensive activity

Other activities
Hepatoprotective effects

Increases the serum levels of SOD and decreases the serum levels of AST, ALT and MDA

Increases the serum levels of SOD and decreases the serum levels of TG, TC, MDA, AST and ALT

Anti-Staphylococcus aureus; Anti-Escherichia coli K12

Exhibits fungicidal activity against Botrytis cinerea, Erysiphe graminis, Phytophthora infestans, Puccinia recondita, Phacelia grisea, and Rhizoctonia solani.

Anti-Helicobacter pylori

Anti-Clostridium

perfringens; Anti-

E. coli

Anti-Fusarium oxysporum;

Anti-B. cinerea

Accelerates the oxidation

of deoxyribose; inhibits

linoleic acid peroxidation

Scavenges free oxygen radicals

Inhibits superoxide radicals

Decreases MDA serum levels

Scavenges hydroxyl

and superoxide radicals

Scavenges DPPH radicals

Antioxidant effect

Scavenges DPPH radicals

Reduces arterial blood pressure

Hypotensive activity

Decreases the blood pressure

Estrogenic activity

Inhibits histamine release

from mast cells

Anti-platelet aggregation

Antigenotoxic activity

Antimutagenic activity
Methanol extract

In vitro

Aqueous extract

In vivo

Ethanol extract

In vivo

Naphthalenes,

In vitro

anthraquinones

In vitro

Ethanol and aqueous

In vitro

extracts

1,2-dihydroxyanthraquinone In vitro

Chloroform extract

In vitro

Water extract

In vitro

Water extract

In vitro

Water-soluble

In vitro

polysaccharides

Water-soluble

In vitro

polysaccharides

Water-soluble

In vitro

polysaccharides

Ethyl acetate fraction In vitro

Methanol extract

In vitro

Alaternin, cassiaside and rubrofusarin-6-O-

In vitro

$\beta$-D-gentiobioside

Water extract

In vivo

Water extract

In vivo

Ethanol extract

In vitro

$70 \%$ EtOH extract

In vitro

Cassiaside $\mathrm{C}_{2}$

In vitro

Gluco-aurantioobtusin

In vitro

Water extract

In vitro

Anthraquinone

In vitro

aglycones and

naphthopyrone

glycosides 
Table II. Continued.

\begin{tabular}{llcc}
\hline $\begin{array}{l}\text { Pharmacological } \\
\text { activities }\end{array}$ & Actions & Extracts/compounds & Application \\
\hline & $\begin{array}{l}\text { Improves myocardial } \\
\text { function and attenuates } \\
\text { MI/R-induced injury }\end{array}$ & Water extract & In vivo \\
\hline
\end{tabular}

TC, total cholesterol; TG, triglyceride; LDL-C, low-density lipoprotein cholesterol; HDL-C, high-density lipoprotein cholesterol; PPAR $\gamma$, peroxisome proliferator-activated receptor; SREBP-1c, sterol regulatory element-binding protein-1c; HSL, hormone-sensitive lipase; TGH, triacylglycerol hydrolase; FAS, tumor necrosis factor receptor superfamily member 6; AGEs, advanced glycation end products; TGF-1, transforming growth factor-1; ECM, extracellular matrix; RAGE, receptor for advanced glycosylation end product; COX-2, cyclooxygenase-2; CTGF, connective tissue growth factor; Smad3/6, mothers against decapentaplegic homolog 3 and 6; AChE, acetylcholinesterase; pCREB, phosphorylated cyclic AMP response element binding protein; BDNF, brain-derived neurotrophic factor; DA, dopaminergic; MDA, malondialdehyde; MAO, monoamine oxidase; SOD, superoxide dismutase; AST, aspartate transaminase; ALT, alanine transaminase; DPPH, 1-diphenyl-2-picrylhydrazyl; MI/R, myocardial ischemia and reperfusion.

were effective substances during hypolipidemic activities $(71,72)$. These results were verified by a previous study, which applied an experimental hyperlipidemic rat model to investigate anthraquinone treatment $(80$ and $20 \mathrm{mg} / \mathrm{kg}$, per os, for 20 days). The TC, TG and LDL-C levels were significantly reduced in a dose-dependent manner, however, the levels of HDL-C increased. Inhibition of cholesterol synthesis may be one of the underlying mechanisms involved in decreasing blood lipid levels (73). Water-soluble polysaccharides (WSPs) from Cassiae semen markedly inhibited the activities of $\alpha$-amylase and pancreatic lipase, however, protease activity increased. The results demonstrated that WSPs had the ability to bind to bile acids and reduce the absorption of cholesterol, indicating that WSPs may have potential as an effective herbal ingredient in functional food applications (74).

Antidiabetic activity. A number of studies have demonstrated that Cassiae semen exhibits anti-diabetic activity. A total of three naphthopyrone glucosides (compounds 49, 52 and 55) isolated from the butanol-soluble extract of Cassia semen have been evaluated for their inhibitory activity on advanced glycation end products (AGEs) formation in vitro. The results revealed that these compounds possessed more potent inhibitory activity against AGEs compared with the aminoguanidine positive control (15). In addition, rubrofusarin-6-O- $\beta$ d-gentiobioside (compound 49) and cassiaside (compound 52) significantly inhibited the expression of transforming growth factor (TGF)-1 and extracellular matrix protein in glomerular mesangial cells cultured under diabetic conditions, suggesting that the active compounds in Cassiae semen may be effective in the treatment of renal complications associated with diabetes (16). Similarly, Kim et al (75) evaluated the preventive effects of the methanol extract of Cassia semen ( $200 \mathrm{mg} / \mathrm{kg} / \mathrm{day}$, for 12 weeks) on the development of diabetic nephropathy in streptozotocin (STZ)-induced diabetic rats. The results indicated that oral treatment with the Cassia semen methanol extract inhibited the development of diabetic nephropathy by inhibiting AGEs accumulation, receptor for advanced glycosylation end product and cyclooxygenase- 2 expression in the renal cortex of STZ-diabetic rats $(75,76)$. In addition, Zhu (77) reported that the water extract of Cassia semen exhibited protective activity against STZ-induced renal fibrosis in diabetic rats. The underlying mechanisms may be associated with its ability to downregulate the expression of TGF- $\beta 1$, connective tissue growth factor and mothers against decapentaplegic homolog 3 (smad3), as well as upregulating the protein expression of smad6 (77).

Neuroprotective activity. The ethanolic extract from the seeds of $C$. obtusifolia has been reported to have a neuroprotective effect in brain disease models. Kim et al (6) suggested that C. obtusifolia $(25,50$ or $100 \mathrm{mg} / \mathrm{kg})$ significantly attenuated scopolamine or transient bilateral common carotid artery occlusion (2VO)-induced memory impairment. These effects are mediated by the enhancement of the cholinergic nervous system via acetylcholinesterase inhibition in a dose-dependent manner [half maximal inhibitory concentration $\left.\left(\mathrm{IC}_{50}\right)=81.6 \mu \mathrm{g} / \mathrm{ml}\right]$ (6). In addition, $C$. obtusifolia (10 or $50 \mathrm{mg} / \mathrm{kg} /$ day) exhibited a neuroprotective effect in a mouse transient global ischemia model due to its anti-inflammatory properties and the induced upregulated expression of phosphorylated cyclic AMP response element binding protein and brain-derived neurotrophic factor (78).

Drever et al (79) demonstrated that treatment with C. obtusifolia $(0.1-10 \mu \mathrm{g} / \mathrm{ml})$ significantly attenuated secondary calcium dysregulation and cell death induced by N-methyl-D-aspartate and 3-nitropropionic acid in mouse hippocampal cultures, and no significant effect on cell death was induced by incubation with naturally-secreted oligomers of amyloid (A) B. Yi et al (80) reported for the first time, that $C$. obtusifolia $(10 \mu \mathrm{g} / \mathrm{ml})$ ameliorated the $\mathrm{A} \beta$-induced synaptic dysfunction model through anti-inflammatory and protein kinase B (Akt)/glycogen synthase kinase- $3 \beta$ pathways. The results suggested that the neuroprotective effect may be attributable to obtusifolin (compound 9) and/or alaternin (compound 17) (80). In a further experiment, $C$. obtusifolia $(0.1-1 \mu \mathrm{g} / \mathrm{ml})$ inhibited cell damage against oxidopamine (6-OHDA)-induced dopaminergic (DA) neural toxicity in $\mathrm{PC} 12$ cells through an anti-oxidant and antimitochondrial-mediated apoptosis mechanism. In a mesencephalic DA culture, C. obtusifolia $(0.1-1 \mu \mathrm{g} / \mathrm{ml})$ protected the DA cells against 6-OHDA- and N-methyl-4-phenylpyridinium iodide-induced 
<smiles>[R]c1cc(O)c2c(c1)C(=O)c1cc([R])cc(O)c1C2=O</smiles><smiles>[R]c1cc2c(c([R])c1[R])C(=O)c1c(cc(C)c(O)c1OC)C2=O</smiles><smiles>COc1cc(O)cc2c1C(=O)c1cc(C)cc(O)c1C2=O</smiles>

$1 \mathrm{R}_{1}=\mathrm{CH}_{3}, \mathrm{R}_{2}=\mathrm{OH}$

$6 \mathrm{R}_{1}=\mathrm{OH}, \mathrm{R}_{2}=\mathrm{OCH}_{3}, \mathrm{R}_{3}=\mathrm{OCH}_{3}$

10

$2 \mathrm{R}_{1}=\mathrm{CH}_{3}, \mathrm{R}_{2}=\mathrm{H}$

$7 \mathrm{R}_{1}=\mathrm{OCH}_{3}, \mathrm{R}_{2}=\mathrm{OCH}_{3}, \mathrm{R}_{3}=\mathrm{OCH}_{3}$

$3 \mathrm{R}_{1}=\mathrm{CH}_{3}, \mathrm{R}_{2}=\mathrm{OCH}_{3}$

$8 \quad \mathrm{R}_{1}=\mathrm{OH}, \mathrm{R}_{2}=\mathrm{OCH}_{3}, \mathrm{R}_{3}=\mathrm{OH}$

$4 \mathrm{R}_{1}=\mathrm{CH}_{2} \mathrm{OH}, \mathrm{R}_{2}=\mathrm{OH}$

$9 \mathrm{R}_{1}=\mathrm{OH}, \mathrm{R}_{2}=\mathrm{H}, \mathrm{R}_{3}=\mathrm{H}$

$5 \mathrm{R}_{1}=\mathrm{COOH}, \mathrm{R}_{2}=\mathrm{H}$<smiles>[R]c1cc2c(c([R])c1[R])C(=O)c1c(cc(C)c(O)c1O)C2=O</smiles>

$11 \mathrm{R}_{1}=\mathrm{OH}, \mathrm{R}_{2}=\mathrm{OCH}_{3}, \mathrm{R}_{3}=\mathrm{OH}$

$12 \mathrm{R}_{1}=\mathrm{OH}, \mathrm{R}_{2}=\mathrm{OCH}_{3}, \mathrm{R}_{3}=\mathrm{OCH}_{3}$

$13 \mathrm{R}_{1}=\mathrm{OCH}_{3}, \mathrm{R}_{2}=\mathrm{OCH}_{3}, \mathrm{R}_{3}=\mathrm{OCH}_{3}$<smiles>Cc1cc(O)c2c(c1)C(C1c3cccc(O)c3C(=O)c3c(O)cc(C)cc31)c1cccc(O)c1C2=O</smiles>

14<smiles>COc1cc2c(cc1C)C(=O)c1c(O)cc(O)cc1C2=O</smiles>

18

$16 \mathrm{R}=\mathrm{OCH}_{3}$

$17 \mathrm{R}=\mathrm{OH}$<smiles>[R]c1cccc2c1C(=O)c1c(O)cc(C)cc1C2</smiles><smiles>[R]c1cc2c(c(O)c1[R3])C(=O)c1c(cc(C)c([R])c1OC)C2=O</smiles>

$20 \mathrm{R}=\mathrm{OH}$

$22 \mathrm{R}_{1}=\mathrm{H}, \mathrm{R}_{2}=\mathrm{OH}, \mathrm{R}_{3}=\mathrm{H}$

$21 \mathrm{R}=\mathrm{OCH}_{3}$
$23 \mathrm{R}_{1}=\mathrm{OCH}_{3}, \mathrm{R}_{2}=\mathrm{H}, \mathrm{R}_{3}=\mathrm{H}$

$24 \mathrm{R}_{1}=\mathrm{OCH}_{3}, \mathrm{R}_{2}=\mathrm{OH}, \mathrm{R}_{3}=\mathrm{OCH}_{3}$<smiles>O=C1c2ccccc2C(=O)c2c1ccc(O)c2O</smiles>

15<smiles>O=Cc1ccc2c(c1)C(=O)c1cc(C=O)cc(O)c1C2=O</smiles>

19

Figure 1. Chemical structures of anthraquinones.

toxicities. In addition, C. obtusifolia $(50 \mathrm{mg} / \mathrm{kg} / \mathrm{day}$ for 15 days) significantly protected DA neuronal degeneration in a 1-methyl-4-phenyl-1,2,3,6-tetrahydropyridine-induced mouse Parkinson's disease (PD) model by inhibiting the movement impairment and the loss of DA neurons, indicating that C. obtusifolia may be a useful neuroprotective candidate for PD (81). In addition, protein and anthraquinone glucosides from Cassia semen improved learning and memory capacity, inhibited the malondialdehyde (MDA) and monoamine oxidase levels, and enhanced the level of superoxide dismutase (SOD) in the cerebrum of senile mice (82).

Hepatoprotective activity. It was recorded in the Compendium of Materia Medica that Cassiae semen exhibited the functions 
<smiles>[R2]c1cc([R7])c2c(c1)C(=O)c1cc(C)cc(O)c1C2=O</smiles>

$26 \mathrm{R}_{1}=\mathrm{OH}, \mathrm{R}_{2}=\mathrm{O}$-glc

$27 \mathrm{R}_{1}=\mathrm{O}$-glc, $\mathrm{R}_{2}=\mathrm{OCH}_{3}$

$28 \mathrm{R}_{1}=\mathrm{O}$-glc-glc, $\mathrm{R}_{2}=\mathrm{OCH}_{3}$

$29 \mathrm{R}_{1}=\mathrm{O}$-glc-glc, $\mathrm{R}_{2}=\mathrm{H}$<smiles>[R]c1c(C)cc2c(c1OC)C(=O)c1c(O)cccc1C2=O</smiles>

$30 \mathrm{R}=\mathrm{O}$-glc<smiles>[R]c1c(C)cc2c(c1[R])C(=O)c1c(O)cc(O)cc1C2=O</smiles>

$31 \mathrm{R}_{1}=\mathrm{O}$-glc-glc, $\mathrm{R}_{2}=\mathrm{H}$

$32 \mathrm{R}_{1}=\mathrm{O}$-glc, $\mathrm{R}_{2}=\mathrm{OH}$

$33 \mathrm{R}_{1}=\mathrm{OH}, \mathrm{R}_{2}=\mathrm{O}$-glc<smiles>[R]c1cc2c(c([R3])c1OC)C(=O)c1c(cc(C)c([R])c1OC)C2=O</smiles>

$34 \mathrm{R}_{1}=\mathrm{OH}, \mathrm{R}_{2}=\mathrm{O}$-glc, $\mathrm{R}_{3}=\mathrm{OH}$

$35 \mathrm{R}_{1}=\mathrm{O}$-glc, $\mathrm{R}_{2}=\mathrm{OCH}_{3}, \mathrm{R}_{3}=\mathrm{OCH}_{3}$<smiles>[R2]c1cc([R7])c2c(c1)C(=O)c1cc(C)c([R3])c(O)c1C2=O</smiles>

$37 \mathrm{R}_{1}=\mathrm{O}$-glc, $\mathrm{R}_{2}=\mathrm{OH}, \mathrm{R}_{3}=\mathrm{H}$

$38 \mathrm{R}_{1}=\mathrm{O}$-glc, $\mathrm{R}_{2}=\mathrm{H}, \mathrm{R}_{3}=\mathrm{OCH}_{3}$<smiles>[R]c1cc2c(c([R])c1OC)C(=O)c1c(cc(C)c([R])c1OC)C2=O</smiles>

$40 \mathrm{R}_{1}=\mathrm{OCH}_{3}, \mathrm{R}_{2}=\mathrm{H}, \mathrm{R}_{3}=\mathrm{O}$-glc

$41 \mathrm{R}_{1}=\mathrm{OH}, \mathrm{R}_{2}=\mathrm{H}, \mathrm{R}_{3}=\mathrm{O}$-glc

$42 \mathrm{R}_{1}=\mathrm{OH}, \mathrm{R}_{2}=\mathrm{O}$-glc, $\mathrm{R}_{3}=\mathrm{OCH}_{3}$<smiles>[R]c1cc(C)cc2c1C(=O)c1c(O)cccc1C2=O</smiles>

$44 \mathrm{R}=\mathrm{O}$-glc-glc-glc

$45 \mathrm{R}=\mathrm{O}-\mathrm{glc}-\mathrm{glc}$-glc-glc<smiles>COc1c(OC2OC(COC(C)=O)[C@@H](O)[C@H](O)[C@H]2O)c(C)cc2c1C(=O)c1c(O)cccc1C2=O</smiles>

36<smiles>[R]c1c(C)cc2c(c1O)C(=O)c1c(cc(O)c(OC)c1O)C2=O</smiles>

$39 \mathrm{R}=\mathrm{O}-\mathrm{glc}$<smiles>[R]c1cc(OC)c2c(c1)C(=O)c1cc(C)c(OC)c(O)c1C2=O</smiles>

$43 \mathrm{R}=\mathrm{O}-\mathrm{glc}$<smiles>[R]c1c(OC)c(OC)cc2c1C(=O)c1c(O)cc(CO)c(OC)c1C2=O</smiles>

$46 \mathrm{R}=\mathrm{O}-\mathrm{glc}$ 
<smiles>COc1cc(O)c2c(O)c(C(C)=O)c(C)cc2c1</smiles>
47<smiles>[R]c1cc([R2])c2c(O)c3c(=O)cc(C)oc3cc2c1</smiles>

$48 \quad \mathrm{R}_{1}=\mathrm{OCH}_{3} ; \mathrm{R}_{2}=\mathrm{OH}$

$49 \mathrm{R}_{1}=\mathrm{OCH}_{3} ; \mathrm{R}_{2}=\mathrm{O}$-glc-glc

$50 \mathrm{R}_{1}=\mathrm{OCH}_{3} ; \mathrm{R}_{2}=\mathrm{O}$-glc-api

$51 \mathrm{R}_{1}=\mathrm{OCH}_{3} ; \mathrm{R}_{2}=\mathrm{O}$-glc-glc-glc

$52 \mathrm{R}_{1}=\mathrm{OH} ; \mathrm{R}_{2}=\mathrm{O}$-glc

$53 \mathrm{R}_{1}=\mathrm{OH} ; \mathrm{R}_{2}=\mathrm{O}$-glc-glc<smiles>[R]c1cc2cc(OC)cc([R])c2c([R])c1C(C)=O</smiles>

$56 \mathrm{R}_{1}=\mathrm{CH}_{3} ; \mathrm{R}_{2}=\mathrm{OH} ; \mathrm{R}_{3}=\mathrm{O}$-glc-api $57 \mathrm{R}_{1}=\mathrm{CH}_{3} ; \mathrm{R}_{2}=\mathrm{OH} ; \mathrm{R}_{3}=\mathrm{O}$-glc-glc

$58 \mathrm{R}_{1}=\mathrm{CH}_{3} ; \mathrm{R}_{2}=\mathrm{OH} ; \mathrm{R}_{3}=$ O-glc-glc-glc-glc

$59 \mathrm{R}_{1}=\mathrm{O}$-api; $\mathrm{R}_{2}=\mathrm{OCH}_{3} ; \mathrm{R}_{3}=\mathrm{O}$-glc<smiles>COc1cc(O)c2c(O)c3c(cc2c1)CC(C)(O)CC3=O</smiles>

62<smiles>COc1cc(O)c2c(O)c3c(cc2c1)CC(C)(O)COC3=O</smiles>

64<smiles>[R]c1cc(OC)cc2cc(O)c3c(c12)OC(C)CC3=O</smiles><smiles>[R]c1cc(O)c2c(O)c3c(cc2c1)CC(C)(CO)OC3=O</smiles>

$60 \mathrm{R}=\mathrm{O}-\mathrm{glc}-\mathrm{glc}$<smiles>[R]c1cc(OC)cc2cc3cc(C)oc(=O)c3c(O)c12</smiles>

$54 \mathrm{R}=\mathrm{OH}$

$55 \mathrm{R}=\mathrm{O}$-glc-glc
$61 \mathrm{R}=\mathrm{O}$-glc-glc 
<smiles>CCCCCCCCC1CC1CCCCCCC(=O)O</smiles>

\section{9}<smiles></smiles>

70<smiles>CC(C)[C@@H](C)CC[C@H](C)[C@H]1CC[C@H]2[C@@H]3CC=C4C[C@@H](O)CC[C@]4(C)C3CC[C@@]21C</smiles>

72<smiles>CCCC(=O)c1c(O)cc(O)c(C)c1O</smiles>

74<smiles>O=c1c(O)c(-c2ccccc2)oc2cc(O)cc(O)c12</smiles>

78<smiles>O=c1ccoc2cc(O)cc(O)c12</smiles>

75
71<smiles>Oc1ccc(-c2cc3ccc(O)cc3o2)c(O)c1</smiles>

73

\section{$76 \mathrm{R}=\mathrm{OH}$ \\ $77 \mathrm{R}=\mathrm{O}-\mathrm{glc}$}


anthraquinones from Cassiae semen exhibited a protective effect on alcohol-induced acute liver injury in mice by regulating fat metabolism, improving liver function and increasing the mRNA and protein expression levels of PPAR- $\gamma(10,87)$.

Antibacterial activity. Antibacterial activity, an important effect of Cassiae semen, has been comprehensively investigated. Naphthalenes (compounds 47 and 50) and anthraquinones (compounds 1, 4 and 5) isolated from C. tora seeds exhibited significant antibacterial effects on four strains of methicillin-resistant Staphylococcus aureus [minimal inhibitory concentration (MIC) was 2-64 $\mu \mathrm{g} / \mathrm{ml}$ ] and a strain of methicillin-sensitive S. aureus. In addition, rhein (compound 5) and torachrysone (compound 47) from the seeds of $C$. tora exhibited antibacterial activity against Escherichia coli K12 with MIC values of 512 and $128 \mu \mathrm{g} / \mathrm{ml}$, respectively (17). Kim et al (88) were the first to demonstrate that emodin (compound 1) from C. tora seeds has a median lethal dose $\left(\mathrm{LC}_{50}\right)$ value of $0.102,0.163,0.385$ and $0.046 \mathrm{~g} / \mathrm{l}$ against Rhizoctonia solani, Botrytis cinerea, Phytophthora infestans and Erysiphe graminis, respectively, and physcion (compound 3) has an $\mathrm{LC}_{50}$ value of $0.248,0.263,0.518$, and $0.073 \mathrm{~g} / \mathrm{l}$ against $R$. solani, B. cinerea, $P$. infestans and E. graminis, respectively. In addition, the $\mathrm{LC}_{50}$ value of rhein (compound 5) is $0.375,0.478$, and $0.047 \mathrm{~g} / 1$ against $R$. solani, $B$. cinerea and $P$. infestans, respectively (88).

It has been reported that ethanol and aqueous extracts of C. obtusifolia seeds were inhibitory against Helicobacter pylori strains (MIC were 100 and $60 \mu \mathrm{g} / \mathrm{ml}$, respectively) (89). In addition, 1,2-dihydroxyanthraquinone (compound 15) isolated from $C$. obtusifolia seeds was revealed to inhibit the growth of Clostridium perfringens and E. coli., indicating that this drug exhibited potent growth-inhibiting activities towards human intestinal bacteria (90). Li et al (91) demonstrated that the chloroform extract of the seeds of $C$. obtusifolia also exhibited different inhibitory activities against Fusarium oxysporum and B. cinerea $\left(\mathrm{IC}_{50}\right.$ values were $0.57 \mathrm{mg} / \mathrm{ml}$ and $0.97 \mathrm{mg} / \mathrm{ml})$.

Antioxidant activity. The water extract of C. tora seeds accelerated the oxidation of deoxyribose induced by $\mathrm{Fe}^{3+}-\mathrm{EDTA} / \mathrm{H}_{2} \mathrm{O}_{2}$ and exhibited $94 \%$ inhibition of linoleic acid peroxidation at a concentration of $0.2 \mathrm{mg} / \mathrm{ml}$. The underlying mechanisms of this may be mediated by reducing metal ions, scavenging hydroxyl radical and chelating ferrousion $(92,93)$. Xv and $\mathrm{Hu}(94)$ demonstrated that the water extract of Cassiae semen exhibited a potent ability to scavenge free oxygen radicals $\left[\mathrm{IC}_{50}\right.$ values were $2 \mathrm{mg} / \mathrm{ml}$ and $2 \mu \mathrm{g} / \mathrm{ml}$ for hydroxyl radicals $\left(\mathrm{OH}^{-}\right)$and hydrogen peroxide $\left(\mathrm{H}_{2} \mathrm{O}_{2}\right)$, respectively]. WSP from Cassiae semen $(0.022 \mathrm{mg} / \mathrm{ml})$ effectively inhibited superoxide radicals $\left(\mathrm{O}^{2-}\right)$ induced by pyrogallol autoxidation (95). The inhibitory effects of WSP on serum levels of MDA were used to evaluate its antioxidation capabilities. The results demonstrated that WSP decreased MDA serum levels with an $\mathrm{IC}_{50}$ value of $15.80 \%$ (96). In another study, Liu et al (97) optimized the extraction conditions for WSP of Cassiae semen (temperature $80^{\circ} \mathrm{C}$, extraction time $3.5 \mathrm{~h}$, solid-liquid ratio 1:30) and observed that WSP $(94.03 \mu \mathrm{g} / \mathrm{ml})$ had the ability to scavenge hydroxyl and superoxide radicals with scavenging rates of 43.32 and $64.97 \%$, respectively.
In addition, ethyl acetate fraction and n-butanol fraction of Cassiae semen were evaluated by DPPH radical scavenging activity. The results revealed that the ethyl acetate fraction had a lower $\mathrm{IC}_{50}$ value of $56.4 \mathrm{~g} / \mathrm{ml}$, when compared with the value of $80.6 \mathrm{~g} / \mathrm{ml}$ for $\mathrm{n}$-butanol fraction. 1-Desmethylaurantio-obtusin (compound 11) exhibited good scavenging activity on DPPH with an $\mathrm{IC}_{50}$ value of $4.5 \pm 0.7 \mathrm{~g} / \mathrm{ml}$, while aurantio-obtusin-6-O$\beta$-D-glucopyranoside (compound 34 ) and questin (compound 10) exhibited moderate antioxidant activity, and their $\mathrm{IC}_{50}$ values were $103.2 \pm 1.5 \mathrm{~g} / \mathrm{ml}$ and $185.2 \pm 1.8 \mathrm{~g} / \mathrm{ml}$, respectively. When compared with these results, chryso-obtusin (compound 7) and aurantio-obtusin (compound 8) demonstrated weaker antioxidant activity $\left(\mathrm{IC}_{50}>200 \mu \mathrm{g} / \mathrm{ml}\right)(98)$. The methanolic extract of $C$. tora seeds exhibited a high antioxidant activity on lipid peroxidation (99). Similarly, in another study, Yen et al (12) demonstrated that the methanolic extract of C. tora seeds exerted a greater antioxidant activity than the other organic solvents (n-hexane and ethyl acetate). Emodin was also revealed to be an antioxidative component (12). In addition, alaternin (compound 17), cassiaside (compound 52 ) and rubrofusarin-6-O- $\beta$-D-gentiobioside (compound 49) isolated from $C$. tora seeds exhibited good scavenging activity against DPPH radicals with $\mathrm{IC}_{50}$ values of $17.59,32.52$ and $18.04 \mu \mathrm{g} / \mathrm{ml}$, respectively (100).

Hypotensive activity. Aqueous and ethanol extracts of Cassiae semen have been reported to possess hypotensive effects (101). Koo et al (101) reported that the water extract of $C$. tora seeds $(3.75,7.5,15,30,60$ and $250 \mathrm{mg} / \mathrm{kg})$ consistently reduced arterial blood pressure in anesthetized rats. A potential reflex mechanism of this hypotensive action may involve a vagal reflex, which reciprocally inhibits the peripheral vasomotor tone via a reflex reduction in the sympathetic neural outflow to blood vessels (102). In addition, the media portion of the medullary reticular formation has been revealed to be directly involved in the hypotensive effect of $C$. tora seeds (103). Furthermore, the ethanol extract of Cassiae semen significantly decreased blood pressure in hypertensive rats by inhibiting receptor-controlled calcium channels on vessels and regulating the secretion of nitric oxide and inducible nitric oxide synthase (104).

Other activities. In addition to the pharmacological effects described above, Cassiae semen and its ingredients have other pharmacological effects, including estrogenic, anti-allergic, antigenotoxic, anti-aggregatory, antimutagenic and cardioprotective effects. Some of these effects are discussed briefly below.

The estrogenic activity of $C$. obtusifolia seeds was evaluated by a recombinant yeast screening assay. The results revealed that $70 \% \mathrm{EtOH}$ extracts of this drug exhibited estrogenic relative potency [half maximal effective concentration $\left(\mathrm{EC}_{50}\right.$ ) was $60.2 \mu \mathrm{g} / \mathrm{ml}$ ) (105). Cassiaside $\mathrm{C}_{2}$ (compound 66) isolated from C. obtusifolia seeds exhibited a potent anti-allergic activity by inhibiting the histamine release from mast cells induced by antigen-antibody reaction (19). Furthermore, gluco-aurantioobtusin (compound 25) from C. obtusifolia seeds possessed potent inhibitory activities against arachidonic-acid-, ADP- and collagen-induced platelet aggregations (39). Wu and Yen (106) demonstrated that the water extract of $C$. tora seeds exhibited potential 
antigenotoxic activities against the dietary mutagens Glu-P-1 and TrpP-1 in the Ames test and the Comet assay. The potential mechanisms may be associated with neutralization of the reactive intermediate of Trp-P-1 and an antioxidant effect of the tested compounds (106). Anthraquinone aglycones (compounds 2, 7 and 8) and naphthopyrone glycosides (compounds 49 and 52) from C.tora seeds exhibited significant antimutagenic activity in vitro. The mechanism associated with these compounds may be mediated via interactions with a microsomal activating system (14). Fu et al (107) reported that the water extract of Cassiae semen $(10 \mathrm{mg} / \mathrm{kg} / \mathrm{day}$, for one week) effectively improved myocardial function, and attenuated myocardial ischemia and reperfusion-induced injury and apoptosis in diabetic animals, which is potentially attributable to the reduced plasma lipid levels and the triggered cell survival Akt and extracellular signal-regulated kinases $1 / 2$ signaling.

\section{Conclusions}

In traditional Chinese medicine, Cassiae semen has long been used to clean the liver, brighten the eye, loosen the bowel to relieve constipation, and for the treatment of inflammation, photophobia, headaches, dizziness, hyperlipemia and Alzheimer's disease. In addition, Cassiae semen is commonly used in the composition of other herbs. Although modern experiments have confirmed that this drug alone exhibits multiple pharmacological activities, it is important to investigate the molecular mechanisms of Cassiae semen combined with other herbs based on traditional uses.

A number of studies have investigated the effective constituents of Cassiae semen from different batches and geographical areas. HPLC-fingerprint chromatography is a common method to compare the differences (108-111). Zhang et al (3) developed a sensitive and reliable ultra-high-performance liquid chromatography-electrospray ionization-tandem mass spectrometry (UHPLC-ESI-MS/MS) method to evaluate the quality of Cassiae semen through simultaneous determination of 13 components, providing a novel basis for the overall assessment of the quality of this plant. In addition, a novel nonaqueous capillary electrophoresis method was used for the analysis of aurantio-obtusin, emodin and rhein in Cassiae semen with satisfactory results (112). Yang et al (113) was the first to simultaneously determine 7 anthraquinones in rat plasma by UHPLC-MS/MS following oral administration of Cassiae semen extract. These results may support investigations into the bioactivity mechanism and clinical application of this drug (113). Anthraquinones and naphthopyrones are considered to be the major constituents. Therefore, characteristic compounds or a biological index should be established to evaluate the quality and ensure their clinical application is suitable. In the Pharmacopoeia of the People's Republic of China, chrysophanol and aurantio-obtusin are used as the indicator compounds to characterize the quality of Cassiae semen with the minimum contents of 0.20 and $0.080 \%$, respectively (1).

A total of 79 compounds including anthraquinones, naphthopyrones and volatile oil have been isolated and identified from Cassiae semen (Table I; Figs. 1-3). It has also been suggested that certain efforts should be made to isolate and identify novel compounds from Cassiae semen, in order to strengthen its pharmacological profile to develop it further as a candidate for novel drug developments in the future.

Pharmacological studies have revealed that Cassiae semen possesses a variety of biological effects, including anti-hyperlipidemic, anti-diabetic, neuroprotective, hepatoprotective, antimicrobial, anti-oxidant and hypotensive activities $(5,90,93,114,115)$. Extracts and compounds responsible for the pharmacological properties have also been determined, as presented in Table II. Although the pharmacological properties of certain traditional uses of Cassiae semen have been validated, these studies were primarily conducted in vitro $(16,116,117)$. Therefore, the effects of these compounds require verification in vivo. In addition, the association between structure and activity, and the potential synergistic action exerted by the bioactive compounds requires further elucidation. It is anticipated that the comprehensive and current research on the pharmacological activities of extracts, as well as on active molecules isolated from Cassiae semen, provided in this review will inspire novel strategies in therapeutics for curing a number of different ailments.

\section{Acknowledgements}

The present review was financially supported by the Collaborative Innovation Construction Plan of Beijing University of Chinese Medicine (grant no. 2013-XTCX-03).

\section{References}

1. Editorial Committee of Chinese Pharmacopoeia. Chinese Pharmacopoeia, 2015 (eds). Medical Science and Technology Press, Beijing, China, pp145, 2015.

2. Cho SH, Kim TH, Lee NH, Son HS, Cho IJ and Ha TY: Effects of Cassia tora fiber supplement on serum lipids in Korean diabetic patients. J Med Food 8: 311-318, 2005.

3. Zhang W, Wang Y, Wang Q, Yang WJ, Gu Y, Wang R, Song XM and Wang XJ: Quality evaluation of Semen Cassiae (Cassia obtusifolia L.) by using ultra-high performance liquid chromatography coupled with mass spectrometry. J Sep Sci 35: 2054-2062, 2012.

4. Chen JK and Chen TT: Chinese Medical Herbology and Pharmacology. CA: Art of Medicine Press, p803, 2001.

5. Hao YJ, Sang YL and Zhao YQ: The advancement of the studies on the seeds of Cassia obtusifolia. Chinese Tradit Herb Drugs 32: 858-859, 2001.

6. Kim DH, Yoon BH, Kim YW, Lee S, Shin BY, Jung JW, Kim HJ, Lee YS, Choi JS, Kim SY, et al: The seed extract of Cassia obtusifolia ameliorates learning and memory impairments induced by scopolamine or transient cerebral hypoperfusion in mice. J Pharmacol Sci 105: 82-93, 2007.

7. Kitanaka S, Kimura F and Takido M: Studies on the Constituents of seeds of Cassia obusifolia LINN. The structures of two new anthraquinone glycosides. Chem Pharm Bull 33: 1274-1276, 1985.

8. Zhang C, Li GL, Xiao YQ and Pang LZ: Two new glycosides from the seeds of Cassia obtusifolia. Chinese Chem Lett 20: 1097-1099, 2009.

9. Deng ZY, Zhang JW, Li J, Fan YW, Cao SW, Huang RL, Yin YL, Zhong HY and Li TJ: Effect of polysaccharides of cassiae seeds on the intestinal microflora of piglets. Asia Pac J Clin Nutr 16 (Suppl 1): 143-147, 2007.

10. Luo X, Xu X, Huang C, Wu X, Liu J, Lan B and Xu J: Experiment study of total anthraquinone in Cassiae Semen on lipid peroxidation and PPAR-gamma expression in liver tissues of rats with alcoholic fatty liver. Zhongguo Zhong Yao Za Zhi 36: 1654-1658, 2011 (In Chinese).

11. Su H, Wang Z and Tang L: Simultaneous determination of 4 major components in Cassiae Semen obtusifoline by HPLC. Zhongguo Zhong Yao Za Zhi 36: 1327-1329, 2011 (In Chinese). 
12. Yen GC, Chen HW and Duh PD: Extraction and identification of an antioxidative component from Jue Ming Zi (Cassia tora L.). J Agr Food Chem 46: 820-824, 1998.

13. Patil UK, Saraf S and Dixit VK: Hypolipidemic activity of seeds of Cassia tora Linn. J Ethnopharmacol 90: 249-252, 2004.

14. Choi JS, Lee HJ, Park KY, Ha JO and Kang SS: In vitro antimutagenic effects of anthraquinone aglycones and naphthopyrone glycosides from Cassia tora. Planta Med 63: 11-14, 1997.

15. Lee GY, Jang DS, Lee YM, Kim JM and Kim JS: Naphthopyrone glucosides from the seeds of Cassia tora with inhibitory activity on advanced glycation end products (AGEs) formation. Arch Pharm Res 29: 587-590, 2006.

16. Jung DH, Kim YS, Kim NH, Lee J, Jang DS and Kim JS: Extract of Cassiae semen and its major compound inhibit S100b-induced TGF-beta1 and fibronectin expression in mouse glomerular mesangial cells. Eur J Pharmacol 641: 7-14, 2010.

17. Hatano T, Uebayashi H, Ito H, Shiota S, Tsuchiya T and Yoshida T: Phenolic constituents of Cassia seeds and antibacterial effect of some naphthalenes and anthraquinones on methicillin-resistant Staphylococcus aureus. Chem Pharm Bull (Tokyo) 47: 1121-1127, 1999.

18. Das C, Dash S, Sahoo DC, Mohanty A and Rout D: Cassia tora: A phyto-pharmacological overview. Int J Res Ayurveda Pharm 2: $1162-1174,2011$

19. Kitanaka S, Nakayama T, Shibano T, Ohkoshi E and Takido M: Antiallergic agent from natural sources. Structures and inhibitory effect of histamine release of naphthopyrone glycosides from seeds of Cassia obtusifolia L. Chem Pharm Bull (Tokyo) 46: $1650-1652,1998$

20. Deore SL, Khadabadi SS, Kamdi KS, Ingle VP, Kawalkar NG, Sawarkar PS, Patil UA and Vyas AJ: In vitro Anthelmintic activity of Cassia tora. Int J Chem Tech Res 1: 177-179, 2009

21. Editorial Board of Flora of China. Science Publishing House Press, p126, 1988.

22. Du ZX: Comparative identification of Cassiae Semen and Sesbania aculeata Pers. Chinese Pharm J 30: 204-205, 1995

23. Zhu SY, Xv HJ and Xv MG: Comparative identification of Semen Cassiae and Cassia sophera. Chin Tradit Herb Drugs 34: 379-380, 2003.

24. Liu J, Zou CC and Sun ZF: Comparative identification of Cassiae Semen and Cassia occidentalis L. Heilongjiang Med Pharm 29: 63-64, 2006

25. Hu YJ, Wan L, Zhang JX, et al: Identification of Cassia obtusifolia L. by TLC. Lishizhen Med Mater Med Res 17: 2129: 2006.

26. Sun GF: Identification of Cassia obtusifolia L., Cassia tora. and Cassia occidentalis L. by SDS-Polyacrylamide gelelectrophoresis. Tianjin Pharm 8: 69-71, 1996.

27. Wang JB, Zhou X and Hu ZF: Quality evaluation of Cassiae Semen by both indicated component determination and HPLC fingerprint. Chin Tradit Herb Drugs 39: 917-919, 2008.

28. Luo Y, Zhang L, Wang WH and Li B: Components identification in Cassiae Semen by HPLC-IT-TOF MS. Chin J Pharm Anal 35: 1408-1516; 2015

29. Lee HJ, Choi JS, Jung JH and Kang SS: Alaternin glucoside isomer from Cassia tora. Phytochemistry 49: 1403-1404, 1998

30. Chen QD, Xv R, Xv ZN, et al: Progress in studies of active coustituents of anthraquinones and their biological activities from Cassiae Semen. Chins J Mod Appl Pharm 20: 120-123, 2003.

31. DiGiovanni $\mathrm{J}$ and Boutwell RK: Tumor promoting activity of 1, 8-dihydroxy-3-methyl-9-anthrone (chrysarobin) in female SENCAR mice. Carcinogenesis 4: 281-284, 1983.

32. Jia ZB, Chen WW, Jiang JX and DING XL: Study on anthraquinone constituents in the seed of Cassia tora L. Chem Ind Forest Prod 29: 100-102, 2009.

33. Xv YL: Studies on the chemical constituents from Semen Cassiae and the influence of processing. Beijing: Chinese Academy of Medical Sciences 1: 15, 2014

34. Takido M: Studies on the constituents of the seeds of Cassia obtusifolia L. I. The Structure of Obtusifolin. Chem Pharm Bull 6: 397-400: 1958.

35. Takido M: Studies on the constituents of seeds of Cassia obusifolia L. II. The structure of Obtusin, Chryso-obutsin and Aurantio-obyusin. Chem Pharm Bull 8: 246, 1960

36. Kitanaka S and Takido M: Studies on the constituents of the seeds of Cassia obusifolia: The structures of three new anthraquinones. Chem Pharm Bull 32: 860-864, 1984.

37. Tang LY, Wang ZJ, Fu HM, et al: Study on anthraquinones constituents from Semen Cassiae. J Chinese Med Mater 32: 717-719, 2009a.
38. Zhang ZX and Liang YF: Isolation and identification of chemical constituents from seeds of Cassia obtusifolia. China Pharm 23: 1782-1783, 2012

39. Yun-Choi HS, Kim JH and Takido M: Potential inhibitors of platelet aggregation from plant sources, V. Anthraquinones from seeds of Cassia obtusifolia and related compounds. J Nat Prod 53: 630-633, 1990

40. Hao YJ, Sang YL and Zhao YQ: Study on anthraquinone constituents in Cassiae Semen. Chinese Tradit Herb Drugs 34: $18-19,2003$

41. Li CH, Wei XY and Li XE: A new anthraquinone glycoside from the seed of Cassia obtusifolia. Chinese Chem Lett 15: 1448-1450, 2004.

42. Wong SM, Wong MM, Seligmann O and WagnerH: Anthraquinone glycosides from the seeds of Cassia tora. Phytochemistry 28: 211-214, 1989.

43. Tang LY, Wang ZJ, Fu MH, He Y, Wu HW and Huang LQ: A new anthraquinone glycoside from seeds of Cassia obtusifolia. Chinese Chem Lett 19: 1083-1085, 2008.

44. Li G, Xiao Y, Li L, Zhang C and Pang Z: Studies on chemical constituents of roasted seeds of Cassia obtusifolia. Zhongguo Zhong Yao Za Zhi 34: 54-56, 2009 (In Chinese).

45. Tang LY, Wang ZJ, He Y, et al: Glycosides from seeds of Cassia obtusifolia. Chinese J Exp Tradit Med Formulae 15: 35-37, 2009b.

46. Jia ZB and Ding XL: Anthraquinone constituents from seeds of Cassia tora L. J Chinese Med Mater 29: 28-29, 2006.

47. Miyuki K, Eisaku M and Shoji S: Chemical Studies on the Oriental Plant Drugs. XXI. The Constituents of Cassia tora L. (2). A Glycoside of Rubrofusarin. Chem Pharm Bull 17: 458-461, 1969.

48. Shibata S, Morishita E and Kaneda M: Chemical Studies on the Oriental Plant Drugs. XX. The Constituents of Cassia tora L.(1). The Structure of Torachrysone. Chem Pharm Bull 17: 454-457, 1969.

49. Takahashi S and Takido M: Studies on the constituents of the seeds of Cassia tora L. II.(On the purgative crude drugs. VII). The structure of the new naphthopyrone derivative, toralactone. Yakugaku Zasshi 93: 261, 1973.

50. Wong SM, Wong MM, Seligmann O and Wagner H: New antihepatotoxic naphthopyrone glycosides from the seeds of Cassia tora. Planta Med 55: 276-280, 1989.

51. Choi JS, Jung JH, Lee HJ, Lee HJ, Lee JH and Kang SS: A naphthalene glycoside from Cassia tora. Phytochemistry 40: 997-999, 1995.

52. Tianaka S and Takido M: Studies on the constituents of the seeds of Cassia obtusifolia L. The structures of two naphthopyrone glycosides. Chem Pharm Bull 36: 3980-3984, 1988.

53. Kitanaka S and Miehio T: Studies on the constituents of the seeds of Cassia obtusifolia: The structures of two new lactones, isotoralactone and cassialactone. Phytochemistry 20: 1951-1953, 1981.

54. Li L, Zhang C, Xiao YQ, Li W, Yin X, Chen D, Tian G and Wang Y: Glycosides of roasted seeds of Cassia obtusifolia. Zhongguo Zhong Yao Za Zhi 35: 1566-1568, 2010.

55. Wang ZJ, Wu QP, Tang LY, Fu MH, He Y, Gong QF and Hung LQ: Two new glycosides from the genus of Cassia. Chinese Chem Lett 18: 1218-1220, 2007.

56. Li YM: Comparison of volatile components of Cassiae Semen and semen seeds tea. J Med Plants Res 6: 3865-3869, 2012.

57. Jiao SF and Han HD: Studies on chemical constituents of Cassiae Semen. Chinese J Clin Ration Drug Use 3: 81-82, 2010.

58. Wu XH: Study on the chemical constituents, quality control and metabolism of Cassia obtusifolia. Wuhan: Huazhong University of Science and Technology 1: 11-12, 2010.

59. Guan Y and Zhao S: Yishou jiangzhi (de-blood-lipid) tablets in the treatment of hyperlipidemia. J Tradit Chin Med 15: 178-179, 1995.

60. Yang Y, Liu J and Lai XH: Observation on cassia seed tea combined with walking exercise on weight loss in the elderly. Modern Prev Med 40: 2468-2474, 2013.

61. Lai XH: Double intervention of cassia seed tea and sports on older women weight loss. Chinese J Gerontol 31: 2402-2404, 2011.

62. Zhang R, Feng ML and Wu YP: Experimental study on the active situs of fetid cassia seed to reduce blood lipid and their dose-effect relation. China Remedies Clin 5: 183-185, 2005b.

63. Zhang JX, Wan L, Hu YJ, Qu OL and Shi JY: Study on the effective part of reducing blood lipid in Semen Cassiae. Lishizhen Med Mater Med Res 17: 904-905, 2006.

64. Li CH, Li XE and Guo BJ: The effects of Cassia obtusifolia seeds extracts on reducing blood lipid. J South China Normal Univ 98: 29-32: 2002. 
65. Wang YH, Gao L, Zhou WJ and Ma WJ: Effects of ethanol extraction from Cassiae Semen on Serum IL-6 and TNF- $\alpha$ in hyperlipidemia rats. Chinese J Exp Tradit Med Formulae 20: 178-181, 2014

66. He JY, Liu SQ, Peng YF, et al: Study of the Mechanism of Cassia Obtusifolia L in decreasing blood -lipid. China Pharm 14: 202-203, 2003

67. Cho IJ, Lee C and Ha TY: Hypolipidemic effect of soluble fiber isolated from seeds of Cassia tora Linn. In rats fed a high-cholesterol diet. J Agric Food Chem 55: 1592-1596, 2007.

68. Liu SM, Sun C and Xie WH: Effect of Semen Cassiae extracts on expression of lipogenesis genes in hyperlipidemia model mice. Chinese Tradit Herb Drugs 40: 583-587, 2009.

69. Wei N, Lv HR and Liu MF: Study on the chemical constitutions of reducing blood lipid in Cassiae Semen. Guangdong Chem Ind 39: 99-100, 2012.

70. Li BL: The active ingredients of reducing blood lipid in Semen Cassia. China Prac Med 7: 172-173, 2012.

71. Guo CY, Horn W and Pin DD: Extraction and identification of an antioxidative component from Jue Ming Zi (Cassia tora L.) J Agric Food Chem 46: 820-824, 1998.

72. Li XE and Guo BJ: Effects of protein and anthraquinone glucosides from Cassia seed on serum lipid of hyperlipidemia rats. Zhongguo Zhong Yao Za Zhi 27: 374-376, 2002 (In Chinese).

73. Li CH, Li XE, Fang KY and Guo BJ: Effects of anthraquinones from Cassia obtusifolia L. on cholesterol biosynthesis in cells. J Clin Rehabilit Tissue Eng Res 12: 6593-6596, 2008.

74. Huang YL, Chow CJ and Tsai YH: Composition, characteristics, and in-vitro physiological effects of the water-soluble polysaccharides from Cassia seed. Food Chem 134: 1967-1972, 2012.

75. Kim YS, Jung DH, Sohn E, Lee YM, Kim CS and Kim JS: Extract of Cassiae semen attenuates diabetic nephropathy via inhibition of advanced glycation end products accumulation in streptozotocin-induced diabetic rats. Phytomedicine 21: 734-739, 2014.

76. Jung DH, Kim YS, Sohn EJ, et al: Effects of CS, a BuOH-Soluble Fraction of Cassiae Semen Methanolic Extract, on COX-2 Expression in Renal Cortex of STZ-Induced Diabetic Rats and Cultured Glomerular Mesangial Cells. Diabetes 56 pA155-pA155, 2007.

77. Zhu TC: Inhibitory Effects of Cassia Seed on the Renal Fibrosis in Diabetic Rats. Chin J Exp Tradit Med Formulae 18: 315-319, 2012.

78. Kim DH, Kim S, Jung WY, Park SJ, Park DH, Kim JM, Cheong JH and Ryu JH: The neuroprotective effects of the seeds of Cassia obtusifolia on transient cerebral global ischemia in mice. Food Chem Toxicol 47: 1473-1479, 2009.

79. Drever BD, Anderson WG, Riedel G, Kim DH, Ryu JH, Choi DY and Platt B: The seed extract of Cassia obtusifolia offers neuroprotection to mouse hippocampal cultures. J Pharmacol Sci 107: 380-392, 2008

80. Yi JH, Park HJ, Lee S, Jung JW, Kim BC, Lee YC, Ryu JH and Kim DH: Cassia obtusifolia seed ameliorates amyloid $\beta$-induced synaptic dysfunction through anti-inflammatory and Akt/GSK-3ß pathways. J Ethnopharmacol 178: 50-57, 2016.

81. Ju MS, Kim HG, Choi JG, Ryu JH, Hur J, Kim YJ and Oh MS Cassiae semen, a seed of Cassia obtusifolia, has neuroprotective effects in Parkinson's disease models. Food Chem Toxicol 48 2037-2044, 2010.

82. Liu JZ, Lin X, Li XE and Guo BJ: Effect of protein and anthraquinone glucosides from Semen Cassiae on learning and memory capacity and related substances of senile mice induced by D-galactone. Zhongguo Zhong Yao Za Zhi 32: 516-519, 2007 (In Chinese)

83. Jiangsu New Medical College: Encyclopedia of Chinese MateriaMedica, I. Shanghai Science and Technology Press, Shanghai, China pp94984, 1975.

84. Yun HS and Chang IM: Plants with liver protective activities (I) Korean J Pharmacogn 8: 125-129, 1977.

85. Gao Q, Xu H and Chen J: Liver-protective and bowel-lubricating and defecation-promoting effects of crude and processed Semen Cassiae. Tradit Chinese Drug Res Clin Pharmacol 18: 194-196, 2007.

86. Lin DJ and Jin Z: Experimental Study on Protective Effect of Semen Cassiae Extract Against Acute Liver Injury. Lishizhen Med Mater Med Res 17: 214-215, 2006.

87. Niu YF, Zhao T, Zeng T, et al: Study on the protective effect of Cassiae Semen extract against alcohol-induced acute liver injury in mice. J Toxicol 24: 58-61, 2010 .
88. Kim YM, Lee CH, Kim HG and Lee HS: Anthraquinones isolated from Cassia tora (Leguminosae) seed show an antifungal property against phytopathogenic fungi. J Agr Food Chem 52: 6096-6100, 2004

89. Li Y, Xu C, Zhang Q, Liu JY and Tan RX: In vitro anti-Helicobacter pylori action of 30 Chinese herbal medicines used to treat ulcer diseases. J Ethnopharmacol 98: 329-333, 2005.

90. Sung BK, Kim MK, Lee WH, Lee DH and Lee HS: Growth responses of Cassia obtusifolia toward human intestinal bacteria. Fitoterapia 75: 505-509: 2004.

91. Li XH, Gong CR, Cao H, et al: Primary study on inhabiting of the extracts from Cassia obtusifolia seeds against Fusarium oxysporum and Botrytis cinerea. J Shanxi Agric Univ 26: 348-350, 2006.

92. Yen GC and Chung DY: Antioxidant Effects of Extracts from Cassia tora L. Prepared under different degrees of roasting on the oxidative damage to biomolecules. J Agr Food Chem 47: 1326-1332, 1999.

93. Yen GC and Chuang DY: Antioxidant properties of water extracts from Cassia tora $\mathrm{L}$. In relation to the degree of roasting. J Agr Food Chem 48: 2760-2765, 2000.

94. Xv JG and Hu QP: Study on Free Radical Scavenging Capacity by Cassia Seed Water Extract in vitro. Food Sci 27: 73-75, 2006

95. Guo CQ, Yan J, Wu XY, Xu GY, Fan CH and Gou XJ: Study on purification and antioxidation of water-soluble polysaccharide isolated from semen cassia. Food Sci 28: 205-208, 2007.

96. Liu J, Deng ZY and Yu HH: Antioxidation Study on Water-soluble Polysaccharide Isolated from Semen Cassiae. Food Sci 27: 61-63, 2006

97. Liu C, Liu Q, Sun J, Jiang Bb, Yan J: Extraction of water-soluble polysaccharide and the antioxidant activity from Cassiae Semen. J Food Drug Anal 22: 492-499; 2014

98.Zeng H, Liu Q, Wang M, Jiang S, Zhang L, He X, Wang J and Chen X: Target-guided separation of antioxidants from Semen cassia via off-line two-dimensional high-speed counter-current chromatography combined with complexation and extrusion elution mode. J Chromatogr B 1001: 58-65, 2015.

99. Kim SY, Kim JH, Kim SK, Oh MJ and Jung MY: Antioxidant activities of selected oriental herb extracts. J Am Oil Chem Soc 71: 633-640, 1994

100. Choi JS, Lee HJ and Kang SS: Alatemin, cassiaside and rubrofusarin gentiobioside, radical scavenging principles from the seeds of Cassia tora on 1,1-diphenyl-2-picrylhydrazyl (DPPH) radical. Arch Pharm Res 17: 462-466, 1994.

101. Koo A, Wang JC and Li KM: Extraction of hypotensive principles from seeds of Cassia tora. Am J Chin Med (Gard City N Y) 4: 245-248, 1976

102. Koo A, Chan WS and Li KM: A possible reflex mechanism of hypotensive action of extract from Cassia tora seeds. Am J Chin Med (Gard City N Y) 4: 249-255, 1976.

103. Chan SH, Koo A and Li KM: The involvement of medullary reticular formation in the hypotensive effect of extracts from seeds of Cassia tora. Am J Chin Med (Gard City N Y) 4 383-389, 1976

104. Mao WH, Shang QH, Liu AD, et al: Effects of Cassiae Semen Extracts on Vasorelaxation and Its Mechanisms in Rat Aorta. Chin J Hypertens 18: 60-63; 2010.

105. Zhang CZ, Wang SX, Zhang Y, Chen JP and Liang XM In vitro estrogenic activities of Chinese medicinal plants traditionally used for the management of menopausal symptoms. J Ethnopharmacol 98: 295-300, 2005.

106. $\mathrm{Wu} \mathrm{CH}$ and Yen GC: Antigenotoxic properties of Cassia tea (Cassia tora L.): Mechanism of action and the influence of roasting process. Life Sci 76: 85-101, 2004.

107. Fu F, Tian F, Zhou H, Lv W, Tie R, Ji L, Li R, Shi Z, Yu L, Liang $\mathrm{X}$, et al: Semen cassiae attenuates myocardial ischemia and reperfusion injury in high-fat diet streptozotocin-induced type 2 diabetic rats. Am J Chinese Med 42: 95-108, 2014

108. Zhang P and Chen JW: HPLC Fingerprint of Cassiae Semen. Chinese Tradit Herb Drugs 38: 372-375, 2007.

109. Luo W, Liu B, Wang W, et al: HPLC fingerprint chromatogram of Cassiae Semen. J Beijing Univ Tradit Chin Med 32: 115-117, 2009.

110. Wang WY, Zhao Q, Zhang TJ, et al: HPLC Fingerprint and chemical pattern recognition of Cassiae Semen. Chinese Tradit Herb Drugs 40: 1638-1641, 2009.

111. Tang YL, Liang TZ, Zhang HX and Xu JY: Study on fingerprint of Cassiae Semen, ultramicro powder and powder particle. Zhong Yao Cai 34: 1861-1866, 2011 (In Chinese). 
112. Wang N, Wu Y, Wu X, Liang S and Sun $\mathrm{H}$ : A novel nonaqueous capillary electrophoresis method for effective separation and simultaneous determination of aurantio-obtusin, emodin and rhein in semen cassiae and cassia seed tea. Anal Methods 6: 5133-5139, 2014.

113. Yang C, Wang S, Guo X, Sun J, Liu L and Wu L: Simultaneous determination of seven anthraquinones in rat plasma by Ultra High Performance Liquid Chromatography-tandem Mass Spectrometry and pharmacokinetic study after oral administration of Semen Cassiae extract. J Ethnopharmacol 169: 305-313, 2015.

114. Hyun SK, Lee H, Kang SS, Chung HY and Choi JS: Inhibitory activities of Cassia tora and its anthraquinone constituents on angiotensin-converting enzyme. Phytother Res 23: 178-184, 2009.
115. Dhanasekaran M, Ignacimuthu S and Agastian P: Potential hepatoprotective activity of ononitol monohydrate isolated from Cassia tora L. on carbon tetrachloride induced hepatotoxicity in Wistar rats. Phytomedicine 16: 891-895, 2009.

116. Jung HA, Ali MY, Jung HJ, Jeong HO, Chung HY and Choi JS: Inhibitory activities of major anthraquinones and other constituents from Cassia obtusifolia against $\beta$-secretase and cholinesterases. J Ethnopharmacol 191: 152-160, 2016,

117. Wen CC, Shyur LF, Jan JT, Liang PH, Kuo CJ, Arulselvan P, Wu JB, Kuo SC and Yang NS: Traditional Chinese medicine herbal extracts of Cibotium barometz, Gentiana scabra, Dioscorea batatas, Cassia tora and Taxillus chinensis inhibit SARS-CoV replication. J Tradit Complement Med 1: 41-50, 2011. 